\title{
High Glucose Concentration Stimulates NHE-1 Activity in Distal Nephron Cells: the Role of the Mek/Erk1/2/p90RSK and p38MAPK Signaling Pathways
}

\author{
Juliana Martins da Costa-Pessoa ${ }^{a, b}$ Rosélia Santos Damasceno ${ }^{a, b}$ \\ Ubiratan Fabres Machado ${ }^{a}$ Olívia Beloto-Silva ${ }^{a} \quad$ Maria Oliveira-Souza ${ }^{a}$ \\ aDepartment of Physiology and Biophysics, Institute of Biomedical Science, University of São Paulo, \\ São Paulo, Brazil, 'These authors contributed equally to this work
}

\author{
Key Words \\ MDCK cells $•$ Glucose $・$ NHE-1 1 Erk1/2 $・$ p38MAPK
}

\begin{abstract}
Aims: In models of diabetes, distal nephron cells contribute to glucose uptake and oxidation. How these cells contribute to the use of glucose for the regulation of $\mathrm{H}^{+}$extrusion remains unknown. We used Madin-Darby Canine Kidney (MDCK) cells to investigate the effect of acute or chronic high glucose concentration on the abundance and activity of the $\mathrm{Na}^{+} / \mathrm{H}^{+}$exchanger (NHE-1). Methods: Using RT-PCR, we also evaluated the mRNA expression for sodium glucose co-transporters SGLT1 and SGLT2. Protein abundance was analyzed using immunoblotting, and intracellular $\mathrm{pH}\left(\mathrm{pH}_{\mathrm{i}}\right)$ recovery was evaluated using microscopy in conjunction with the fluorescent probe BCECF/AM. The $\mathrm{Na}^{+}$-dependent $\mathrm{pH}_{\mathrm{i}}$ recovery rate was monitored with $\mathrm{HOE}$ $694(50 \mu \mathrm{M})$ and/or S3226 (10 $\mu \mathrm{M})$, specific NHE-1 and NHE-3 inhibitors. Results: MDCK cells did not express the mRNA for SGLT1 or SGLT2 but did express the GLUT2, NHE-1 and NHE3 proteins. Under control conditions, we observed a greater contribution of $\mathrm{NHE}-1$ to $\mathrm{pH}_{\mathrm{i}}$ recovery relative to the other $\mathrm{H}^{+}$transporters. Acute high glucose treatment increased the HOE694-sensitive $\mathrm{pH}_{\mathrm{i}}$ recovery rate and $\mathrm{p}$-Erk1/2 and $\mathrm{p} 90^{\mathrm{RSK}}$ abundance. These parameters were reduced by PD-98059, a Mek inhibitor $(1 \mu \mathrm{M})$. Chronic high glucose treatment also increased the HOE-694-sensitive $\mathrm{pH}_{\mathrm{i}}$ recovery rate and $\mathrm{p}$-p38MAPK abundance. Both parameters were reduced by SB-203580, a p38MAPK inhibitor $(10 \mu \mathrm{M})$. Conclusion: These results suggested that extracellular high glucose stimulated NHE-1 acutely and chronically through Mek/Erk1/2/ p90 ${ }^{\mathrm{RSK}}$ and $\mathrm{p} 38 \mathrm{MAPK}$ pathways, respectively.
\end{abstract}




\section{Introduction}

The fasting plasma glucose concentration is approximately $5 \mathrm{mM}$ and is regulated by insulin and other hormones [1]. The kidneys freely filter glucose, and almost $90 \%$ of this filtered glucose is reabsorbed through the low-affinity, high-capacity $\mathrm{Na}^{+}$-glucose cotransporter SGLT2, which is localized in the brush border membrane of epithelial cells in the $\mathrm{S} 1$ segment of the proximal renal tubule. The remaining $10 \%$ is reabsorbed through the high-affinity, low-capacity $\mathrm{Na}^{+}$-glucose co-transporter SGLT1, which is located in the more distal S3 segment of the proximal tubule [2,3]. Two glucose transporters in the basolateral membrane facilitate a gradient-determined glucose efflux into the interstitium; GLUT2 in the S1 segment, and GLUT1 in the S3 segment [4]. Thus, under physiological conditions, the clearance of glucose is near zero. However, the sustained hyperglycemia of diabetes increases the filtered glucose load beyond the maximal tubular transport rate and thus leads to glycosuria, although an increase of SGLT2 and GLUT2 expression in proximal tubule cells contributes to glucose uptake in this nephron segment $[4,5]$.

It is known that oxidative stress is related to reactive oxygen species (ROS) in the kidneys of diabetic patients [6]. ROS activate multiple signaling pathways that in turn begin phosphorylation cascades involving serine/threonine-specific protein kinases, such as the mitogen-activated protein kinases (MAPKs) Erk1/2 and p38MAPK. These pathways induce cell proliferation, differentiation and apoptosis [7]. Additionally, the distal nephron cells are important for glucose uptake, glycogen storage, glucose oxidation and consequently ROS generation [8]. However, it has not been established in diabetic animals whether distal nephron cells contribute to the use of glucose as a substrate for the regulation of $\mathrm{H}^{+}$extrusion, even though these cells express vacuolar $\mathrm{H}^{+}$-ATPase [9] and $\mathrm{H}^{+} / \mathrm{K}^{+}$-ATPase [10] in the luminal membrane, NHE-1 in the basolateral membrane [11] and NHE-3 [12].

The NHE family contains membrane transport proteins whose key functions are the regulation of intracellular $\mathrm{pH}\left(\mathrm{pH}_{\mathrm{i}}\right)$ and cell volume by catalyzing the secondary active electroneutral exchange of one $\mathrm{Na}^{+}$for one $\mathrm{H}^{+}$[11]. To date, ten NHE isoforms have been cloned in mammalian tissues [13,14]. NHE-1 is highly conserved across vertebrate species, is activated by acidic deviations from steady-state $\mathrm{pH}_{\mathrm{i}}$ and osmotic cell shrinkage, and in renal epithelial cells it is essentially detected in the basolateral membrane [15]. It has been shown that NHE-1 also regulates intracellular events related to cell proliferation [1619]. NHE-1 has two large functional domains: an N-terminal transmembrane domain of approximately 500 amino acids that is responsible for cation translocation, and a cytosolic C-terminal domain of approximately 315 amino acids that is the primary regulatory site for NHE-1 activity [20]. The cytosolic domain contains numerous serine and threonine residues that are phosphorylated by several protein kinases, including the extracellular signal-related kinases Erk1/2, p90 RSK and p38MAPK [13, 20-24].

Thus, it is reasonable to suspect that Erk1/2 and p38MAPK activation may mediate the effect of high glucose in NHE-1 activity in distal nephron cells, which are essential for $\mathrm{Na}^{+}$ and $\mathrm{pH}$ homeostasis. Therefore, we investigated the acute and chronic effects of high glucose concentration on Erk1/2/p90 ${ }^{\mathrm{RSK}}$ and $\mathrm{p} 38 \mathrm{MAPK}$-dependent NHE-1 activity and protein abundance in MDCK cells, which are used as a model of distal nephron cells that express NHE-1 preferentially in the basolateral membrane $[25,26]$.

\section{Materials and Methods}

All of the experimental protocols were conducted in accordance with the ethical standards approved by the Institutional Animal Care and Use Committee (Protocol Number 264, page 8).

Wild-type MDCK cells were obtained from the American Type Culture Collection (ATCC, Manassas, VA, USA). Cells at passage 55 were grown in $75-\mathrm{cm}$ culture flasks containing $5 \mathrm{mM}$ glucose- Dulbecco's 
Modified Eagle's Medium (DMEM) (Invitrogen, SP, Brazil, BR), as has been previously described [27]. For $\mathrm{pH}_{\mathrm{i}}$ experiments, cells were removed from the culture flasks using trypsin and $2.5 \times 10^{5}$ cells were seeded onto 25-mm-diameter glass coverslips inserted into 6-well plates containing complete DMEM medium. The medium was changed every 2 days until the cultures reached $80-90 \%$ confluence. For PCR or immunoblotting experiments, cells were seeded into the 6-well plates and cultured under the same conditions described above. For chronic treatment, the cells were treated with DMEM medium containing $25 \mathrm{mM}$ glucose for 48 hours. For each treatment group, a control group was simultaneously cultured in the presence of $5 \mathrm{mM}$ glucose for comparison.

Reverse transcription (RT) followed by polymerase chain reaction (PCR)

Total RNA was extracted from control MDCK cells with the TRIzol LS Reagent Kit (Invitrogen) for use with RT-PCR. mRNA was amplified from total RNA using random primers, SuperScript ${ }^{\circledR}$ II RT (Invitrogen) and PCR (Applied Biosystems, USA). SGLT1 and SGLT2 mRNA was amplified using PCR and specific primers for SGLT1-Canis Lupus familiaris (forward: 5'ccgacatctctgtcatcgtcatctacttt 3'; reverse: 5'ctgccacagacagcaggatgatg 3'; NCBI: NM-001007141.1) or SGLT2-Canis Lupus familiaris (forward: 5' caccatgatctacactgtgacaggagg 3'; reverse: 5'ccgagacaatggtgagacccag 3'; NCBI: NM-001007142.1) (Invitrogen). cDNA products were resolved on a $1 \%$ agarose gel.

\section{Immunoblotting}

Proteins from control or treated MDCK cells were extracted using ice-cold RIPA buffer (BioRad, Sao Paulo, Brazil) with protease and phosphatase inhibitors (Sigma Aldrich, St. Louis, MO, USA) and centrifugation (3000xg for 5 minutes). Immunoblot analysis was performed on protein aliquots containing $50 \mu \mathrm{g} / \mathrm{lane}$ of proteins resolved in 10\% SDS-PAGE as previously described [27, 28]. The following primary antibodies were used in this study: rabbit anti-Glut2 (1:1000); mouse anti-Erk1/2 (1:1000); mouse antiErk1/2 with phosphorylated Thr and Tyr residues (1:1000) (Merck-Millipore, Darmstadt, Germany); rabbit anti-phospho-p90 ribosomal S6 kinase (p90 $\left.{ }^{\mathrm{RSK}}-\mathrm{Th}^{359} / \mathrm{Ser}^{363}\right)$ (1:1000); rabbit anti-p38MAPK (1:1000); rabbit anti-p38MAPK with phospho-Thr ${ }^{180}$ and - Tyr $^{182}$ (1:1000) (Cell Signaling Technology, Danvers, MA, USA); mouse anti-NHE-1 (1:1000); mouse anti- $\beta$ actin (1:3000) (Abcam, Cambridge, UK); mouse antiNHE-3-4F5 (1:750) (Santa Cruz Biotechnology, SC, CA, USA); and horseradish peroxidase-conjugated goat secondary antibodies against both rabbit and mouse (Jackson ImmunoResearch Laboratories, Baltimore, MD, USA ).

\section{Fluorescent $p$ Hi measurement}

For this study, we used 110 glass coverslips carrying cell monolayers, and the baseline $\mathrm{pH}_{\mathrm{i}}$ was evaluated for each coverslip before acid loading. As described in our previous studies [27-29], intracellular $\mathrm{pH}\left(\mathrm{pH}_{\mathrm{i}}\right)$ was monitored using the BCECF-AM fluorescent probe (Molecular Probes, Eugene, OR, USA). Cells grown to confluence on glass coverslips were fluorescently labeled using $5 \mu \mathrm{M}$ BCECF-AM in control solution [28] for 3 minutes. Intracellular esterases quickly convert BCECF-AM into its anionic acid form. Then, the glass coverslips were rinsed with control solution to remove excess BCECF-containing solution and placed into a thermo-regulated chamber assembled on an inverted epifluorescence microscope (Nikon). The area of the glass coverslips measured under the microscope had a diameter of $260 \mu \mathrm{m}$, and all of the experiments were performed at $37^{\circ} \mathrm{C}$. The cells were alternately excited at 440 or $495 \mathrm{~nm}$ with a $150 \mathrm{~W}$ xenon lamp, and the fluorescence emission was monitored at $530 \mathrm{~nm}$ using a photomultiplier-based fluorescence system (Photon Technology International, PTI) at 5-second intervals. The 495/440 excitation ratio corresponds to a specific $\mathrm{pH}_{\mathrm{i}^{\prime}}$ At the end of each experiment, the BCECF signal was calibrated for 15 minutes using the high $\mathrm{K}^{+}$-nigericin method, which exposes the cells to a high $\mathrm{K}^{+}$solution [(in mM) NaCl-20, $\mathrm{KCl}-130, \mathrm{MgCl}_{2}-1, \mathrm{CaCl}_{2}-$ 1 HEPES-5] containing $10 \mu \mathrm{M}$ nigericin and was adjusted to various $\mathrm{pH}$ values.

\section{Cell $p H i$ recovery}

Because MDCK cells express vacuolar $\mathrm{H}^{+}$-ATPase [9], $\mathrm{H}^{+} / \mathrm{K}^{+}$-ATPase [10] and NHE-3 [12], all $\mathrm{pH}_{\mathrm{i}}$ recovery experiments were performed in the presence of concanamycin $A\left(\mathrm{H}^{+}-\mathrm{ATPase}\right.$ inhibitor, $\left.10 \mu \mathrm{M}\right)$, Schering (Sch.) $28080\left(\mathrm{H}^{+} / \mathrm{K}^{+}\right.$ATPase inhibitor, $1 \mu \mathrm{M}$ ) (Sigma Aldrich) and 3-[2-(3-guanidino-2-methyl-3oxopropenyl)-5-methyl-phenyl]-N-isopropylidene-2-methyl acrylamide dihydrochloride (S3226), an NHE3 inhibitor, $10 \mu \mathrm{M}$ [12]. Control cells exposed to an extracellular glucose concentration of $5 \mathrm{mM}$ or cells 
treated with a high glucose concentration of $25 \mathrm{mM}$ and HOE-694 (NHE-1 inhibitor, $50 \mu \mathrm{M}$ ) [30], PD 98059 (Mek inhibitor, $1 \mu \mathrm{M}$ ) or SB 203580 (p38 MAPK inhibitor, $10 \mu \mathrm{M}$ ) (Merck-Millipore) were submitted to $\mathrm{pH}_{\mathrm{i}}$ recovery analysis. Cellular $\mathrm{pH}_{\mathrm{i}}$ recovery was examined after acid loading using the $\mathrm{NH}_{4} \mathrm{Cl}$ pulse technique [27, 31 ] by exposing the cells to $20 \mathrm{mM} \mathrm{NH}_{4} \mathrm{Cl}$ [(in mM) NaCl-125, KCl-5, $\mathrm{MgCl}_{2}-1, \mathrm{NaH}_{2} \mathrm{PO}_{4}-0.8, \mathrm{Na}_{2} \mathrm{HPO}_{4}-0.83$, $\mathrm{CaCl}_{2}-1$, HEPES-8, glucose-5 and $\mathrm{NH}_{4} \mathrm{Cl}-20$; $\mathrm{pH} 7.4$ ] for 2 minutes. As described in our previous studies [28, 32]. $\mathrm{Na}^{+}$-independent $\mathrm{pH}_{\mathrm{i}}$ recovery was induced by bathing the cells in a $\mathrm{Na}^{+}$-free solution; $\mathrm{NaCl}$ from the control solution was replaced with $138 \mathrm{mM} \mathrm{N}$-methyl-D-glucamine (NMDG) and/or concanamycin A and Sch. 28080, $\mathrm{pH}$ 7.4. $\mathrm{Na}^{+}$-dependent $\mathrm{pH}_{\mathrm{i}}$ recovery was induced by bathing cells in control or high glucose solutions containing either concanamycin A, Sch. 28080, HOE-694, S3226, PD 98059 or SB 203580. For all of the experiments, the initial $\mathrm{pH}_{\mathrm{i}}$ recovery rate was calculated $\left(\mathrm{dpH}_{\mathrm{i}} / \mathrm{dt}\right.$, $\mathrm{pH}$ units $\left./ \mathrm{min}\right)$ during the recovery phase using linear regression analysis. For acute treatment, cells cultured with $5 \mathrm{mM}$ extracellular glucose were exposed to high glucose solution $(25 \mathrm{mM})$ after acid loading. All steps of $\mathrm{pH}_{\mathrm{i}}$ recovery analysis for chronic treatment were performed in the presence of high glucose.

All other chemicals were purchased from Invitrogen or Sigma-Aldrich. The osmolality of all solutions was $300 \mathrm{mOsm} / \mathrm{kg} / \mathrm{H}_{2} \mathrm{O}$, which was similar to the osmolality of the cell culture medium.

\section{Statistical analysis}

All results are presented as the mean \pm standard error (SE), where " $n$ " is the number of coverslips carrying cell monolayers for each group. The statistical significance was assessed by one-way ANOVA followed by the Bonferroni's or Student's t-test. For immunoblot analysis, values were expressed as a percentage of the respective control, and statistical significance was assumed at $\mathrm{p}<0.05$

\section{Results}

\section{Glucose transporters and NHE expression}

First, we evaluated the expression of several glucose transporters and the $\mathrm{Na}^{+} / \mathrm{H}^{+}$ exchanger in MDCK cells. These results demonstrate that SGLT1 or SGLT2 expression was not detected in MDCK cells using RT-PCR (Fig. 1A). However, MDCK cells are known to express endogenous GLUT1 [22], and our results (Fig. 1B) demonstrated that this cell line also expressed the GLUT2 protein. In addition to glucose transporters, MDCK cells also expressed the NHE-1 and NHE-3 proteins (Fig. 1C), confirming previous studies [12, 27, 28, 32].

\section{Acute high glucose treatment and $\mathrm{pH}_{i}$ recovery}

MDCK cells in $\mathrm{HCO}_{3}$-free solution had a mean $\mathrm{pH}_{\mathrm{i}}$ baseline of $7.14 \pm 0.05(\mathrm{n}=110$ coverslips) and a representative trace of $\mathrm{pH}_{\mathrm{i}}$ recovery (Fig. 2A) showed that, after acid loading with $\mathrm{NH}_{4} \mathrm{Cl}$ and $138 \mathrm{mM} \mathrm{NMDG}$, the re-addition of a $\mathrm{Na}^{+}$solution containing a low glucose concentration plus concanamycin-A and Sch. 28080 induced $\mathrm{pH}_{\mathrm{i}}$ recovery to values approaching the baseline level.

Using linear regression analysis, the $\mathrm{pH}_{\mathrm{i}}$ recovery rate was calculated during the recovery phase after acid loading for all $\mathrm{pH}_{\mathrm{i}}$ experimental groups. The results (Fig. 2B) indicated that, after acid loading, the mean $\mathrm{pH}_{\mathrm{i}}$ recovery rate was $0.249 \pm 0.023 \mathrm{pH}$ units/ $\min (\mathrm{n}=10)$ under control conditions. However, this value was significantly reduced by a solution containing S3226, concanamycin-A and Sch. 28080 [0.178 $\pm 0.022 \mathrm{pH}$ units/min (n =9)], which suggested the involvement of NHE-3 and only the additional significant effect of HOE-694 confirms NHE- 1 activity $[0.038 \pm 0.010 \mathrm{pH}$ units $/ \mathrm{min}(\mathrm{n}=7)]$. Thus, to evaluate the effect of glucose in NHE-1 activity, cells were then treated with S3226, concanamycin-A and Sch. 28080.

We also investigated whether an increased extracellular glucose concentration affects the HOE-694-sensitive $\mathrm{pH}_{\mathrm{i}}$ recovery rate. Our results (Fig. 2C) indicate that, under the condition of high glucose, the $\mathrm{pH}_{\mathrm{i}}$ recovery rate showed a notable rise in $\mathrm{pH}$ units $/ \mathrm{min}$ relative to the control [high glucose: $0.365 \pm 0.013(n=11)$ versus the control: $0.178 \pm 0.022$ $(\mathrm{n}=9)$ ]. To confirm the specific effects of 5 or $25 \mathrm{mM}$ glucose on NHE-1 activity, we used mannitol, an impermeable and un-metabolized solute, as an osmotic control. As shown 
Fig. 1. Glucose and sodium transporters expression in MDCK cells. (A) Representative agarose gel $(1 \%)$ of three experiments showing the $\beta$-actin band (198 bp) and the absence of SGLT1 and SGLT2; the bands expected for these proteins were 223 and $184 \mathrm{bp}$ in size, respectively. $M$ indicates the marker (1 kb DNA plus ladder). (B) Representative immunoblot

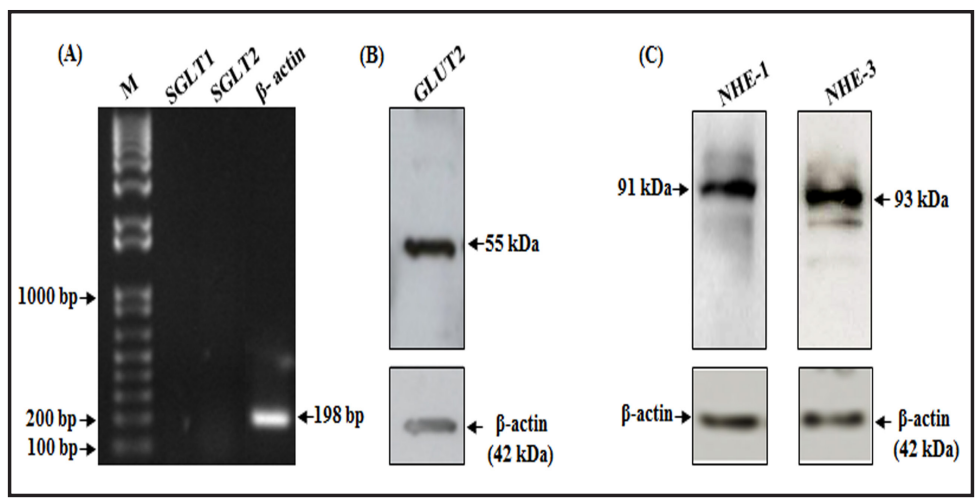
$(n=4)$ of the GLUT2 protein. (C) Representative immunoblot $(n=3)$ for detection of NHE-1 and NHE-3. All blots were further probed to detect $\beta$-actin to normalize protein loading. $b p=$ base pairs.

Fig. 2. The acute effect of high glucose concentration in the $\mathrm{pH}_{\mathrm{i}}$ recovery. (A) Representative experiment of $\mathrm{pH}_{\mathrm{i}}$ recovery. (B) The effect of S3226, HOE-694 concanamycinA (Conc. A) and Schering (Sch) 28080, in the $\mathrm{pH}_{\mathrm{i}}$ recovery rate. (C) The effect of high glucose or mannitol in the HOE-694-sensitive $\mathrm{pH}_{\mathrm{i}}$ recovery rate. The results from 8 to 11 experiments are shown as mean \pm S.E. ${ }^{*} \mathrm{p}<0.05$ relative to Canc.A plus Sch 28080 treated group; ${ }^{*} \mathrm{p}<$ 0.05 relative to the control (5 mM glucose).
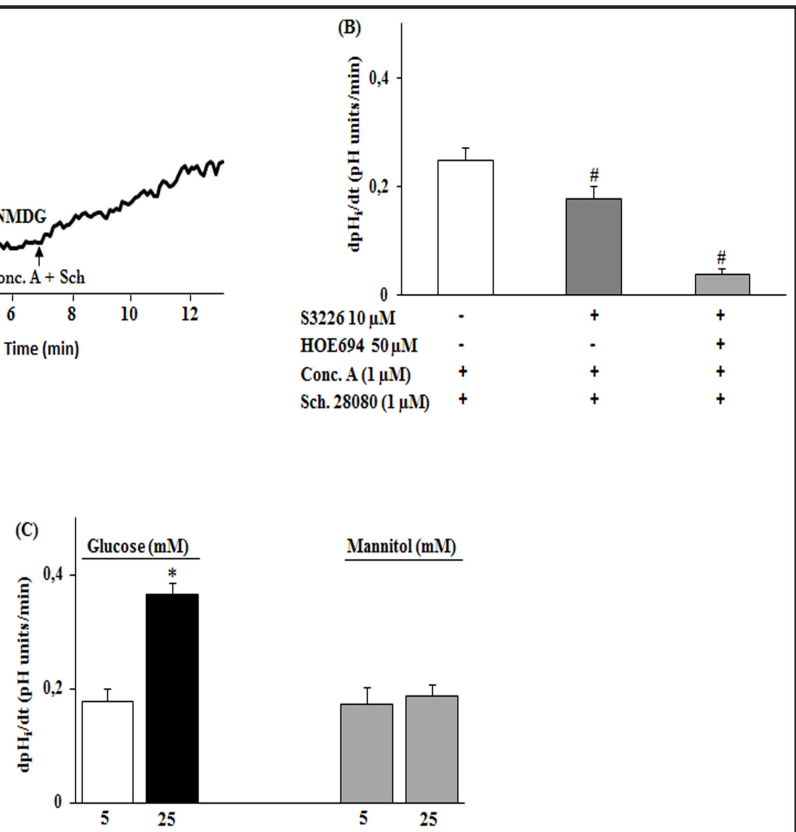

in Fig. 2C, treatment with either 5 or $25 \mathrm{mM}$ mannitol did not modify the HOE-694-sensitive $\mathrm{pH}_{\mathrm{i}}$ recovery rate in $\mathrm{pH}$ units/min relative to the control [5 mM mannitol: $0.172 \pm 0.030$ $(n=8)$ or $25 \mathrm{mM}$ mannitol: $0.187 \pm 0.019(n=8)$ versus $5 \mathrm{mM}$ glucose: $0.178 \pm 0.022(n=9)]$. These results confirmed that the stimulatory effect of high glucose on NHE-1 was not related to any osmotic effect.

The effect of acute high glucose concentration on the pHi recovery rate is partially mediated by the Mek/Erk1/2/p90RSK pathway

We examined whether the acute stimulatory effect of high glucose in NHE-1 activity was mediated by the Mek/Erk1/2 pathway. For this experiment, the cells were previously treated with PD 98059 (a Mek inhibitor) for 20 minutes, and, after acid loading, they were exposed to control and high glucose concentration solutions with or without PD 98059 for the evaluation of the $\mathrm{pH}_{\mathrm{i}}$ recovery rate. As shown in Fig. 3A, PD 98059 did not change the HOE-694-sensitive $\mathrm{pH}_{\mathrm{i}}$ recovery rate under control conditions ( $5 \mathrm{mM}$ glucose) but did decrease the acute stimulatory effect of $25 \mathrm{mM}$ glucose (in $\mathrm{pH}$ units/min) [control: $0.178 \pm$ $0.022(\mathrm{n}=9)$; PD 98059: $0.182 \pm 0.013(\mathrm{n}=10) ; 25 \mathrm{mM}$ glucose: $0.365 \pm 0.025(\mathrm{n}=11) ; 25$ $\mathrm{mM}$ glucose plus PD 98059: $0.231 \pm 0.021(\mathrm{n}=11)]$. When growth factors stimulate cells, NHE- 1 activation is known to be related to the phosphorylation of serine $703\left(\mathrm{Ser}^{703}\right)$ by 
Fig. 3. The stimulatory effect of acute high glucose concentration in the $\mathrm{pH}_{\mathrm{i}}$ recovery rate is partially mediated by the Mek/Erk1/2/p90 RSK pathway. (A) Effect of glucose and/or PD 98059 in the HOE 694-sensitive $\mathrm{pH}_{\mathrm{i}}$ recovery rate. The results from 9 to 11 experiments are shown as mean \pm S.E. (B) Representative immunoblots ( $\mathrm{n}$ = 5) for detection of p-Erk1/2 and unphosphorylated Erk1/2 and the normalization of protein loading. (C) Densitometric analysis of the immunoblots (ratio of phosphorylated to total Erk1/2) is shown as the percentage of the control. (D) Representative immunoblots (n $=4$ ) for detection of $\mathrm{p}-\mathrm{p} 90^{\mathrm{RSK}}$. The blots were further probed
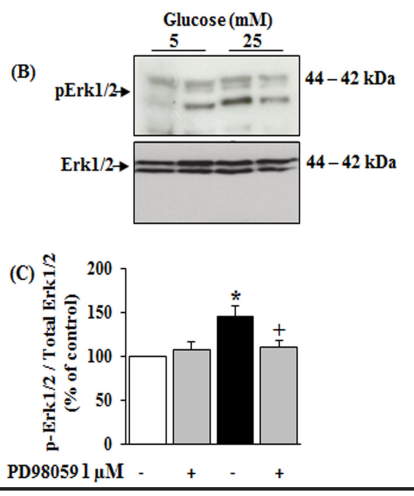
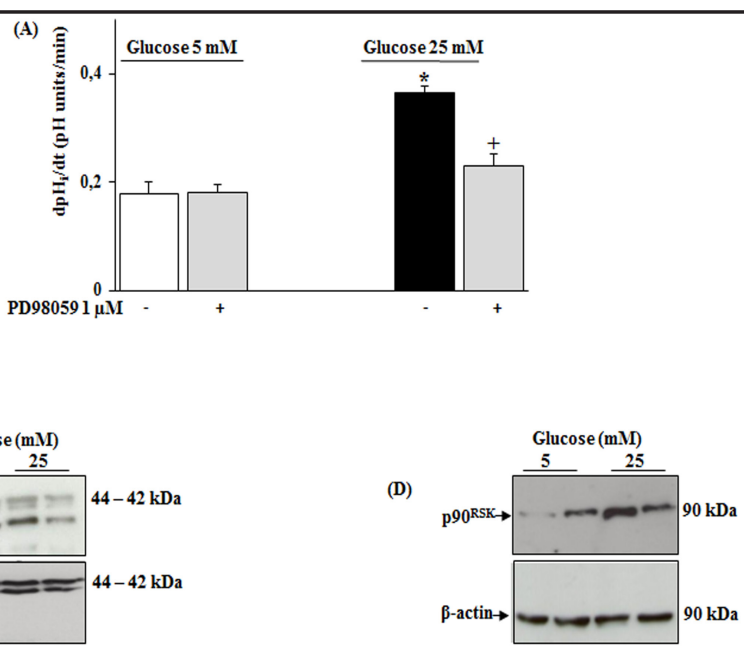

(E)

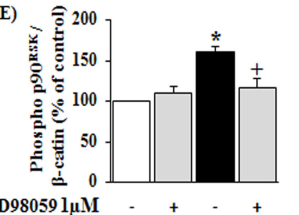

for $\beta$-actin to normalize protein loading. (E) Densitometric analysis of the immunoblots $(n=4)$ is shown as the percentage of the control. ${ }^{*} \mathrm{p}<0.05$ relative to the control ( $5 \mathrm{mM}$ glucose); ${ }^{+} \mathrm{p}<0.05$ relative to $25 \mathrm{mM}$ glucose.

p $90^{\mathrm{RSK}}$, which is directly regulated by Erk1/2 [33, 34]. Thus, we next evaluated the effect of acute high glucose concentration and/or PD 98059 on the total and phosphorylated fractions of Erk1/2. As shown in Fig. 3B and C, treatment with an acute high glucose concentration induced a significant increase in the abundance of the Erk1/2-phosphorylated fraction. PD 98059 did not change Erk1/2 abundance under control conditions but did decrease the stimulatory effect of an acute high glucose concentration on this parameter [PD 98059: $107 \pm 10 \%$ relative to the control; $25 \mathrm{mM}$ glucose: $145 \pm 12 \%$ relative to the control; 25 $\mathrm{mM}$ glucose plus PD 98059: $110 \pm 9 \%$ relative to $25 \mathrm{mM}$ glucose]. Similarly, a high glucose concentration also increased the abundance of the $\mathrm{p} 90^{\mathrm{RSK}}$-phosphorylated fraction in a PD98059-sensitive manner (Fig. 3D and E) [PD 98059: $111 \pm 8 \%$ relative to the control; $25 \mathrm{mM}$ glucose: $161 \pm 6$ relative to the control; and $25 \mathrm{mM}$ glucose plus PD 98059: $117 \pm$ 11 relative to $25 \mathrm{mM}$ glucose]. These results confirmed that, in MDCK cells, the acute highglucose-induced increase in the $\mathrm{pH}_{\mathrm{i}}$ recovery rate involves Mek/Erk1/2/p90 ${ }^{\text {RSK}}$-mediated NHE-1 activity.

\section{Chronic high glucose treatment increases the $\mathrm{pHi}$ recovery rate}

Cells were treated with a control ( $5 \mathrm{mM})$ or high glucose concentration $(25 \mathrm{mM})$ for 48 hours as described above, and $\mathrm{pH}_{\mathrm{i}}$ recovery was evaluated. The results (Fig. $4 \mathrm{~A}$ ) revealed that the chronic high glucose treatment increased the HOE-694-sensitive $\mathrm{pH}_{\mathrm{i}}$ recovery rate (in pH units/min) [Control: $0.180 \pm 0.019(\mathrm{n}=8)$ and high glucose 48 hours: $0.449 \pm 0.022(\mathrm{n}$ $=10)]$. This effect was not related to regulation of NHE-1 protein expression, since the total NHE- 1 abundance remained unchanged (Fig. 4B and C) [high glucose 48 hours: $117 \pm 11 \%$ relative to the control].

The chronic effect of high glucose concentration on the pHi recovery rate is partially mediated by $\mathrm{p} 38 \mathrm{MAPK}$ phosphorylation

It is known that p38MAPK can phosphorylate NHE-1 under different conditions [23]. Thus, we evaluated whether the chronic stimulatory effect of high glucose in NHE-1 activity 


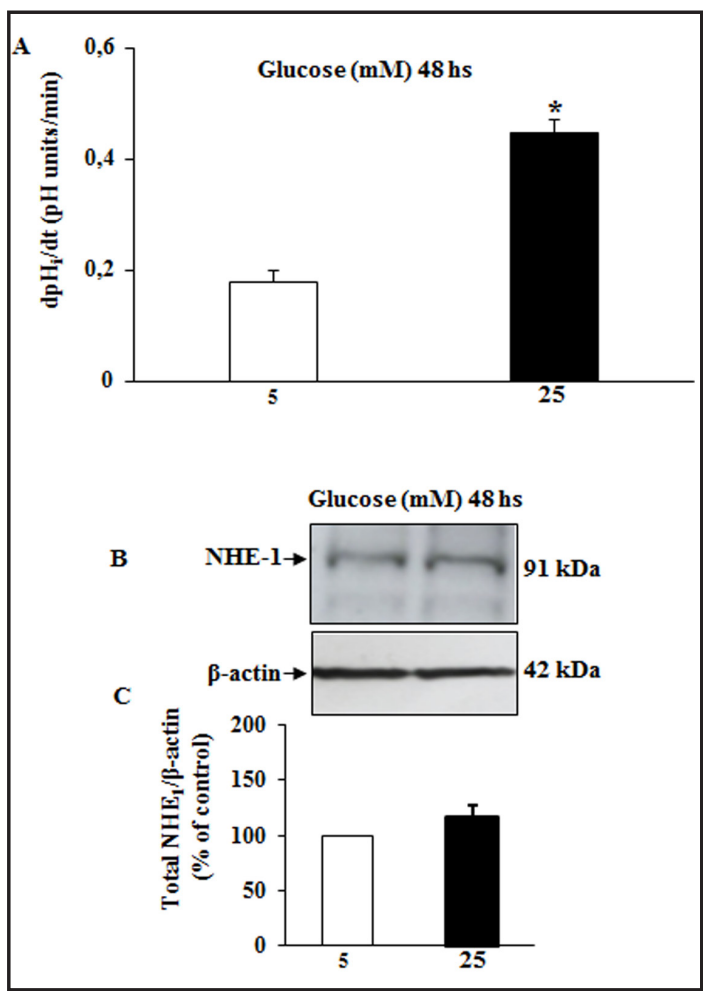

Fig. 4. The chronic effects of high glucose concentration in NHE-1 activity and expression. The cells were treated with a control or high concentration of glucose for 48 hours. (A) The $\mathrm{pH}_{\mathrm{i}}$ recovery rate was evaluated after acid loading in the presence of concanamycin-A, Sch. 28080 and S3226. The results from 8 to 10 experiments are shown as mean \pm S.E. ${ }^{*} \mathrm{p}<0.05$ relative to the control ( $5 \mathrm{mM}$ glucose). (B) Representative immunoblots $(n=5)$ for detection of NHE-1. The blots were further probed to detect $\beta$-actin to normalize protein loading. (C) The densitometric analysis of immunoblots is shown as a percentage of the total NHE-1 (NHE-1/ $\beta$-actin).

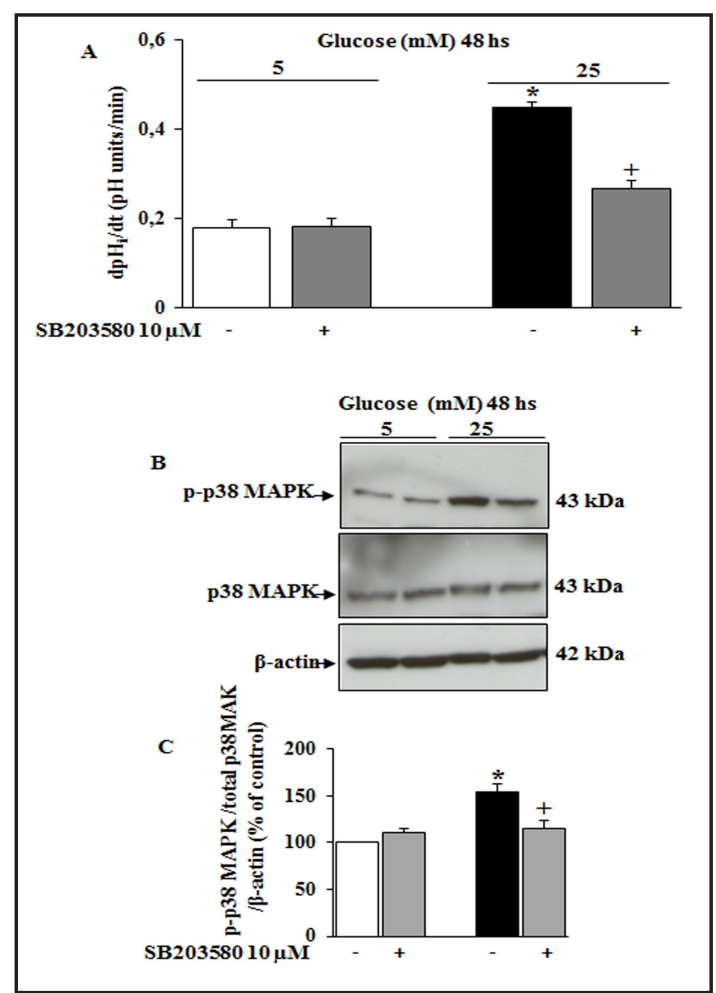

Fig. 5. The effect of glucose and/or SB 203580 in the HOE-694-sensitive $\mathrm{pH}_{\mathrm{i}}$ recovery. (A) The results of 8 to 10 experiments are shown as mean \pm S.E. ${ }^{*} p$ $<0.05$ relative to the control $\left(5 \mathrm{mM}\right.$ glucose); ${ }^{+} \mathrm{p}<$ 0.05 relative to high glucose. (B) Representative immunoblots $(n=5)$ for detection of phosphorylated and unphosphorylated p38MAPK. The blots were further probed to detect $\beta$-actin to normalize protein loading. (C) Densitometric analysis of the immunoblots (p-p38MAPK/(p38MAPK/ $\beta$-actin) is shown as a percentage of the control. ${ }^{*} p<0.05$ relative to the control ( $5 \mathrm{mM}$ glucose); ${ }^{+} \mathrm{p}<0.05$ relative to high glucose.

was mediated by the p38MAPK pathway. For this experiment, the cells were previously treated with SB 203580 (a p38MAPK inhibitor) for 20 minutes, and, after acid loading, they were exposed to control and high glucose concentration solutions with or without SB 203580 for the evaluation of the $\mathrm{pH}_{\mathrm{i}}$ recovery rate. Our results (Fig. 5A) indicated that SB 203580 did not change the HOE-694-sensitive $\mathrm{pH}_{\mathrm{i}}$ recovery rate under the control condition of $5 \mathrm{mM}$ glucose but did decrease the stimulatory effect of high glucose on this parameter (in $\mathrm{pH}$ units $/ \mathrm{min}$ ) [control: $0.180 \pm 0.019(n=8)$; SB 203580: $0.183 \pm 0.018(n=8)$; high glucose: $0.449 \pm 0.022$ $(n=10)$; high glucose plus SB 203580: $0.269 \pm 0.017(n=10)]$, indicating that, under chronic high glucose conditions, activated p38MAPK appears to regulate NHE-1 activity. In addition, we evaluated the effect of chronic high glucose on p38MAPK abundance. As shown in Fig. 5 (B and C), this treatment increased the fraction of phosphorylated p38MAPK. SB 203580 did not change the abundance of the phosphorylated p38MAPK fraction under the control condition of $5 \mathrm{mM}$ glucose but instead decreased the stimulatory effect of chronic high (25 $\mathrm{mM}$ ) glucose [SB 203580: $110 \pm 5 \%$ ) relative to the control; chronic high glucose: $154 \pm 9 \%$ relative to the control; high glucose plus SB 203580: $115 \pm 9 \%$ relative to high glucose]. 


\section{Discussion}

Despite that glucose excretion represents a significant health risk; the effects of hyperglycemia and/or glycosuria in the distal nephrons of the kidney have not been extensively studied. In this study, we used MDCK cells, which contain endogenous GLUT1, a protein that is predominantly targeted to the cell basolateral domain [22]. We observed that MDCK cells under the control condition also express endogenous GLUT2 but not SGLT1 or SGLT2. These results suggest that GLUT1 and GLUT2 contribute to glucose uptake in distal nephron cells during extracellular high glucose exposition, therefore these regulations may be important in diabetes mellitus.

In distal nephron cells, the oxidation of intracellular glucose is an important event that may contribute to oxidative stress and, consequently, MAPK stimulation [7, 21, 35-37]. Interestingly, MAPKs such as Erk1/2 and p38 regulate cellular proliferation, differentiation and apoptosis, and these cellular events are also related to NHE-1 activation [13, 21].

Various studies have reported that a high level of extracellular glucose has a positive effect in NHE activity in enterocytes, mesangial cells and the brush border membrane of the renal proximal tubules [38-40]. However, the role of extracellular high glucose in NHE-1 activity of the distal nephron remains unknown. In our study, we evaluated the acute and chronic effect of high glucose in NHE-1 activity and the cell signaling pathways associated with the regulation of this protein. We did not investigate oxidative stress because Khandelwal et al. [8] have demonstrated that distal nephron cells have an active glucose oxidation process.

Initially, we confirmed the expression of NHE-1 and NHE-3 in MDCK cells and demonstrated that NHE-1 had a greater effect in the $\mathrm{pH}_{\mathrm{i}}$ recovery rate after acid loading. We then investigated whether NHE-1 is activated by high glucose treatment. Indeed, acute high glucose treatment increased the HOE-694 sensitive $\mathrm{pH}_{\mathrm{i}}$ recovery rate compared with the control ( $5 \mathrm{mM}$ glucose), indicating a significant and osmolarity-independent effect of glucose in NHE-1 activity.

Searching for signaling mechanisms that may regulate NHE-1 activity during acute high glucose treatment, we focused our attention on the Mek/Erk1/2/p90 $0^{\mathrm{RSK}}$ pathway because several hormones and growth factors are known to regulate NHE-1 via the MAPK family [33]. In previous studies, there has been some controversy concerning the method of Erk $1 / 2$ activation, and different stimuli have been applied over the course of minutes, hours or days [24]. In this study, cells were treated with PD 98059 followed by $\mathrm{pH}_{\mathrm{i}}$ evaluation. Our results suggest that there may be a significant contribution of the Mek/Erk1/2 pathway on this parameter. The remaining stimulatory effect of high glucose suggests that other mechanisms may also contribute for NHE-1 activation by high glucose. Under these same conditions, we observed that acute high glucose increased the fractions of phosphorylated Erk1/2 and p90 ${ }^{\text {RSK }}$, confirming that the stimulatory effect of acute high glucose on NHE-1 was related to Mek/Erk1/2/p90 $0^{\mathrm{RSK}}$ pathway activation. These findings are in accordance with other studies that have observed that the Erk1/2/p90 RSK pathway regulates NHE- 1 activity because NHE1 activation by serum in mammalian cells is dependent on the phosphorylation of $\mathrm{Ser}^{703}$ by $\mathrm{p} 90^{\mathrm{RSK}}$. This process is, in turn, directly regulated by Erk1/2 [24,33].

Considering our results using acute treatment, we evaluated the effect of chronic high glucose on NHE-1 abundance and activity. We also evaluated the contribution of the Mek/ Erk1/2 or p38MAPK pathways on NHE-1abundance and activity. For this, MDCK cells were treated with concentrations of 5 or $25 \mathrm{mM}$ glucose for 5, 20, 25 and 48 hours and after acid loading, the HOE-694-sensitive $\mathrm{pH}_{\mathrm{i}}$ recovery rate increased in a time-dependent manner [5, 20 and 25 hours (data not shown)]. Because the maximum effect of chronic high glucose in the HOE-694-sensitive $\mathrm{pH}_{\mathrm{i}}$ recovery rate was observed at 48 hours of treatment, we confirmed the contribution of NHE-1 activity to $\mathrm{pH}_{\mathrm{i}}$ regulation under these conditions. NHE1 abundance did not change, however, indicating that the effect of high glucose on NHE-1 activity may be associated with specific phosphorylation sites.

The Mek/Erk1/2 pathway can also be activated by chronic stimuli, including thrombin, fibroblast growth factor, hormones and glucose [24, 37]. Given the observation of a chronic 
high-glucose-induced effect in the HOE-694-sensitive $\mathrm{pH}_{\mathrm{i}}$ recovery rate, we speculated that the Mek/Erk1/2 pathway may mediate the chronic high-glucose-induced stimulatory effect on NHE-1. However, our results demonstrated that PD 98059 did not change the HOE-694sensitive $\mathrm{pH}_{\mathrm{i}}$ recovery rate (data not shown). These results suggest that, in MDCK cells, the stimulatory effect of chronic high glucose concentration in NHE-1 activity at 48 hours of treatment was not mediated by the Mek/Erk1/2 signaling pathways.

Glucose-induced p38MAPK activation is known to occur up to 24 hours after a change in glucose levels [36]. In addition, Khaled et al. [23] have observed that p38MAPK directly phosphorylates NHE-1 at one threonine $\left(\mathrm{Thr}^{717}\right)$ and three serines $\left(\mathrm{Ser}^{722}, \mathrm{Ser}^{725}\right.$ and $\left.\mathrm{Ser}^{728}\right)$. However, p38MAPK did not appear to phosphorylate the p90 ${ }^{\mathrm{RSK}}$ target site $\left(\mathrm{Ser}^{703}\right)$ in NHE1 [23]. In part, our results are in accordance with these findings because SB 203580 partially reduced the effect of chronic high glucose concentrations on both the HOE-694-sensitive $\mathrm{pH}_{\mathrm{i}}$ recovery rate and p38MAPK abundance, confirming the interaction of NHE-1 with p38MAPK during chronic high glucose treatment. On the other hand, the remaining stimulatory effect observed on both parameters suggests that in addition other mechanisms, may also contributes to the regulation of NHE-1 activity during chronic high glucose treatment.

The physiological relevance of the present study is related to the enhanced knowledge of cellular signaling surrounding the effects of glucose on NHE-1 activity in the distal nephron, which is essential for glucose, $\mathrm{Na}^{+}$and $\mathrm{pH}$ homeostasis. Furthermore, since important regulations were also observed in response to chronic high glucose concentration, these effects may play important role in the renal pathophysiology of diabetic subjects.

In conclusion, we demonstrated that an acute or chronic high glucose treatment induced a significant increase in the HOE-694-sensitive $\mathrm{pH}_{\mathrm{i}}$ recovery rate in MDCK cells through the activation of NHE-1 protein. In addition, we demonstrated that the stimulatory effect in NHE- 1 activity induced by acute high glucose was mediated by the Mek/Erk1/2/p90 RSK pathway. Alternatively, the effect of chronic high glucose in NHE-1 activity was mediated by p38MAPK; without participation of Erk1/2 pathway.

\section{Acknowledgments}

The authors would like to thank Karina Thieme for her suggestions and Dr. Margarida de Mello Aires and Dr. Gerhard Malnic for providing some of the drugs used in this study, especially the S3226. This work was supported by the Fundação de Amparo a Pesquisa do Estado de São Paulo (FAPESP) (grant numbers 07/58966-7; 12/04831-1) and the Conselho Nacional de Desenvolvimento Científico e Tecnológico (CNPq) (grant number 471946/2009-5).

\section{Conflicts of Interest}

The authors declare no conflicts of interest in the preparation of this article.

\section{References}

1 Tirosh A, Shai I, Tekes-Manova D, Israeli E, Pereg D, Shochat T, Kochba I, Rudich A: Normal fasting plasma glucose levels and type 2 diabetes in young men. N Engl J Med 2005;353:1454-1462.

- Wright EM: Renal Na+-glucose cotransporters. Am J Physiol Renal Physiol 2001;280:F10-18.

3 Wright EM, Loo DD, Hirayama BA: Biology of human sodium glucose transporters; Physiol Rev 2011;91:733-794.

4 Rahmoune H, Thompson PW, Ward JM, Smith CD, Hong G, Brown J: Glucose transporters in human renal proximal tubular cells isolated from the urine of patients with non-insulin-dependent diabetes; Diabetes 2005;54:3427-3434. 


\section{Cellular Physiology Cell Physiol Biochem 2014;33:333-343 \begin{tabular}{ll|l} 
and BiOChemistry & $\begin{array}{l}\text { DOI: 10.1159/000356673 } \\
\text { Published onlıne: February 05, } 2014\end{array}$ & $\begin{array}{l}\text { C 2014 S. Karger AG, Basel } \\
\text { www.karger.com/cpb }\end{array}$ \\
\cline { 2 - 3 }
\end{tabular}}

5 Vestri S, Okamoto MM, de Freitas HS, Aparecida Dos Santos R, Nunes MT, Morimatsu M, Heimann JC, Machado UF: Changes in sodium or glucose filtration rate modulate expression of glucose transporters in renal proximal tubular cells of rat. J Membr Biol 2001;182:105-112.

-6 Du XL, Edelstein D, Rossetti L, Fantus IG, Goldberg H, Ziyadeh F, Wu J, Brownlee M: Hyperglycemia-induced mitochondrial superoxide overproduction activates the hexosamine pathway and induces plasminogen activator inhibitor-1 expression by increasing sp1 glycosylation. Proc Natl Acad Sci USA 2000;97:1222212226.

7 Friederich-Persson M, Thörn E, Hansell P, Nangaku M, Levin M, Palm F: Kidney hypoxia, attributable to increased oxygen consumption, induces nephropathy independently of hyperglycemia and oxidative stress. Hypertension 2013;62:914-919.

-8 Khandelwal RL, Zinman SM, Knull HR: The effect of streptozotocin-induced diabetes on glycogen metabolism in rat kidney and its relationship to the liver system. Arch Biochem Biophys 1979;197:310316.

9 Douglas JG: Angiotensin receptor subtypes of the kidney cortex. Am J Physiol 1987;253:F1-7.

10 Feifel E, Krall M, Geibel JP, Pfaller W: Differential activities of $\mathrm{H}^{+}$extrusion systems in mdck cells due to extracellular osmolality and ph. Am J Physiol 1997;273:F499-506.

11 Fliegel L: The $\mathrm{Na}^{+} / \mathrm{H}^{+}$exchanger isoform 1; Int J Biochem Cell Biol 2005;37:33-37.

12 Su HW, Yeh HH, Wang SW, Shen MR, Chen TL, Kiela PR, Ghishan FK, Tang MJ: Cell confluence-induced activation of signal transducer and activator of transcription-3 (stat3) triggers epithelial dome formation via augmentation of sodium hydrogen exchanger-3 (nhe3) expression. J Biol Chem 2007;282:9883-9894.

13 Orlowski J, Grinstein S: Diversity of the mammalian sodium/proton exchanger slc9 gene family. Pflugers Arch 2004;447:549-565.

14 Lee SH, Kim T, Park ES, Yang S, Jeong D, Choi Y, Rho J: Nhe10, an osteoclast-specific member of the $\mathrm{Na}^{+}$/ $\mathrm{H}^{+}$exchanger family, regulates osteoclast differentiation and survival [corrected]. Biochem Biophys Res Commun 2008;369:320-326.

15 Biemesderfer D, Reilly RF, Exner M, Igarashi P, Aronson PS: Immunocytochemical characterization of $\mathrm{Na}^{+}$/ $\mathrm{H}^{+}$exchanger isoform nhe-1 in rabbit kidney. Am J Physiol 1992;263:F833-840.

16 Ritter M, Fuerst J, Wöll E, Chwatal S, Gschwentner M, Lang F, Deetjen P, Paulmichl M: $\mathrm{Na}^{+} / \mathrm{H}^{+}$exchangers: Linking osmotic dysequilibrium to modified cell function. Cell Physiol Biochem 2001;11:1-18.

17 Wu S, Song T, Zhou S, Liu Y, Chen G, Huang N, Liu L: Involvement of $\mathrm{Na}^{+} / \mathrm{H}^{+}$exchanger 1 in advanced glycation end products-induced proliferation of vascular smooth muscle cell. Biochem Biophys Res Commun 2008;375:384-389.

18 Aravena C, Beltrán AR, Cornejo M, Torres V, Díaz ES, Guzmán-Gutiérrez E, Pardo F, Leiva A, Sobrevia L, Ramírez MA: Potential role of sodium-proton exchangers in the low concentration arsenic trioxideincreased intracellular ph and cell proliferation. PLoS One 2012;7:e51451.

19 Li K, Su W, Li M, Chen CJ, Li YY, Lai LY, Zhang MM, Liu SJ, Fichna J, Peng A, Hao CM, Gu Y, Lin SY: Acid loading stimulates rat glomerular mesangial cells proliferation through $\mathrm{Na}^{+} / \mathrm{H}^{+}$exchanger isoform 1 (nhe1)dependent pathway. Naunyn Schmiedebergs Arch Pharmacol 2013;386:563-569.

20 Wakabayashi S, Pang T, Su X, Shigekawa M: A novel topology model of the human $\mathrm{Na}^{+} / \mathrm{H}^{+}$exchanger isoform 1. J Biol Chem 2000;275:7942-7949.

21 Gunasegaram S, Haworth RS, Hearse DJ, Avkiran M: Regulation of sarcolemmal $\mathrm{Na}^{+} / \mathrm{H}^{+}$exchanger activity by angiotensin ii in adult rat ventricular myocytes: Opposing actions via at(1) versus at(2) receptors. Circ Res 1999;85:919-930.

22 Pascoe WS, Inukai K, Oka Y, Slot JW, James DE: Differential targeting of facilitative glucose transporters in polarized epithelial cells. Am J Physiol 1996;271:C547-554.

23 Khaled AR, Moor AN, Li A, Kim K, Ferris DK, Muegge K, Fisher RJ, Fliegel L, Durum SK: Trophic factor withdrawal: P38 mitogen-activated protein kinase activates nhe1, which induces intracellular alkalinization. Mol Cell Biol 2001;21:7545-7557.

24 Luo J, Kintner DB, Shull GE, Sun D: Erk1/2-p90rsk-mediated phosphorylation of $\mathrm{Na}^{+} / \mathrm{H}^{+}$exchanger isoform 1. A role in ischemic neuronal death; J Biol Chem 2007;282:28274-28284.

25 Noel J, Roux D, Pouysségur J: Differential localization of $\mathrm{Na}^{+} / \mathrm{H}^{+}$exchanger isoforms (nhe1 and nhe3) in polarized epithelial cell lines. J Cell Sci 1996;109:929-939. 


\section{Cellular Physiology Cell Physiol Biochem 2014;33:333-343 and Biochemistry

26 Odunewu A, Fliegel L: Acidosis-mediated regulation of the nhe1 isoform of the $\mathrm{Na}^{+} / \mathrm{H}^{+}$exchanger in renal cells. Am J Physiol Renal Physiol 2013;305:F370-381.

-27 Costa-Pessoa JM, Figueiredo CF, Thieme K, Oliveira-Souza M: The regulation of nhe1 and nhe3 activity by angiotensin ii is mediated by the activation of the angiotensin ii type i receptor/phospholipase c/calcium/ calmodulin pathway in distal nephron cells. Eur J Pharmacol 2013;721:322-331.

-28 Thieme K, Eguti DM, Mello-Aires M, Oliveira-Souza M: The effect of angiotensin ii on intracellular ph is mediated by at(1) receptor translocation; Am J Physiol Cell Physiol 2008;295:C138-145.

-29 Eguti DMN, Thieme K, Leung GP, Mello-Aires M, Oliveira-Souza M: Regulation of $\mathrm{Na}^{+} / \mathrm{H}^{+}$exchanger isoform 1 (nhe1) by calmodulin-binding sites: Role of angiotensin ii. Cell Physiol Biochem 2010;26:541-552.

30 Putney LK, Denker SP, Barber DL: The changing face of the $\mathrm{Na}^{+} / \mathrm{H}^{+}$exchanger, nhe1: Structure, regulation, and cellular actions. Annu Rev Pharmacol Toxicol 2002;42:527-552.

-31 Boron WF, De Weer P: Intracellular ph transients in squid giant axons caused by co2, nh3, and metabolic inhibitors. J Gen Physiol 1976;67:91-112.

-32 Oliveira-Souza M, De Mello-Aires M: Interaction of angiotensin ii and atrial natriuretic peptide on ph(i) regulation in mdck cells. Am J Physiol Renal Physiol 2000;279:F944-953.

-33 Takahashi E, Abe J, Gallis B, Aebersold R, Spring DJ, Krebs EG, Berk BC: P90(rsk) is a serum-stimulated Na ${ }^{+}$/ $\mathrm{H}^{+}$exchanger isoform-1 kinase. Regulatory phosphorylation of serine $703 \mathrm{of} \mathrm{Na}^{+} / \mathrm{H}^{+}$exchanger isoform- 1 . J Biol Chem 1999;274:20206-20214.

-34 Lehoux S, Abe J, Florian JA, Berk BC: 14-3-3 binding to $\mathrm{Na}^{+} / \mathrm{H}^{+}$exchanger isoform-1 is associated with serum-dependent activation of $\mathrm{Na}^{+} / \mathrm{H}^{+}$exchange; J Biol Chem 2001;276:15794-15800.

35 Moor AN, Gan XT, Karmazyn M, Fliegel L: Activation of $\mathrm{Na}^{+} / \mathrm{H}^{+}$exchanger-directed protein kinases in the ischemic and ischemic-reperfused rat myocardium; J Biol Chem 2001;276:16113-16122.

-36 Hu Z, Wang Y, Graham WV, Su L, Musch MW, Turner JR: Mapkapk-2 is a critical signaling intermediate in nhe3 activation following $\mathrm{Na}^{+}$-glucose cotransport. J Biol Chem 2006;281:24247-24253.

-37 Estañ MC, Calviño E, de Blas E, Boyano-Adánez MeC, Mena ML, Gómez-Gómez M, Rial E, Aller P: 2-deoxyd-glucose cooperates with arsenic trioxide to induce apoptosis in leukemia cells: Involvement of igf-1rregulated akt/mtor, mek/erk and lkb-1/ampk signaling pathways. Biochem Pharmacol 2012;84:16041616.

-38 Zhao H, Shiue H, Palkon S, Wang Y, Cullinan P, Burkhardt JK, Musch MW, Chang EB, Turner JR: Ezrin regulates nhe3 translocation and activation after $\mathrm{Na}^{+}$-glucose cotransport; Proc Natl Acad Sci USA 2004;101: 9485-9490.

-39 Lin R, Murtazina R, Cha B, Chakraborty M, Sarker R, Chen TE, Lin Z, Hogema BM, de Jonge HR, Seidler U, Turner JR, Li X, Kovbasnjuk O, Donowitz M: D-glucose acts via sodium/glucose cotransporter 1 to increase nhe3 in mouse jejunal brush border by a $\mathrm{Na}^{+} / \mathrm{H}^{+}$exchange regulatory factor 2-dependent process. Gastroenterology 2011;140:560-571.

40 Ganz MB, Hawkins K, Reilly RF: High glucose induces the activity and expression of $\mathrm{Na}^{+} / \mathrm{H}^{+}$exchange in glomerular mesangial cells. Am J Physiol Renal Physiol 2000;278:F91-96. 